\title{
Quality of Life and Level of Physical Activity in Sports Education Students During the COVID-19 Pandemic
}

\author{
Faridha Nurhayati ${ }^{1, *}$ Endang S. Wahjuni ${ }^{1,}$ Dony Andrijanto ${ }^{1,}$ Irma Febriyanti ${ }^{1,}$ \\ Arifah Kaharina ${ }^{1}$
}

\author{
${ }^{1}$ Sport Science Faculty, Universitas Negeri Surabaya, Indonesia \\ *Corresponding author: faridhanurhayati@unesa.ac.id
}

\begin{abstract}
This study aims to determine the quality of life and the level of physical activity of sports education students at Surabaya State University during the COVID-19 pandemic. This research is a quantitative descriptive study with a survey method. The population is all sports education students in sports science faculty, Surabaya State University. The research subjects were determined by purposive sampling, 2019th students who entered the inclusion criteria, as many as 159 students consisting of 115 men and 44 women. The test instrument in the form of a questionnaire was adapted from WHO Quality of Life-BREF (WHOQOL-BREF) to measure quality of life and the International Physical Activity Questionnaire (IPAQ) to measure the level of physical activity. Data were analyzed univarietaly with a frequency distribution. The results showed the quality of life in sports education students during the COVID-19 pandemic on the dimensions of physical health in the good category $(54.46 \pm 9.27)$, the dimensions of psychological health in the good category $(61.99 \pm 10.85)$, the dimensions of social health in the good category $(65.12 \pm 13.69)$, and the dimensions of the environment health in the good category $(61.85 \pm 12.62)$. The level of physical activity showed a low category of 5 students (3.1\%), a moderate category of 61 students (38.4\%), and a height category of 93 students (58.5\%). It can be concluded that even during the COVID-19 pandemic with online teaching and learning activities, most students had a good quality of life and high physical activity. It is very necessary to maintain the quality of life and always improve the health and fitness of the body to avoid transmission of COVID-19.
\end{abstract}

Keywords: Quality of life, Level of physical activity, Sports education, Students, COVID-19

\section{INTRODUCTION}

In early 2020, COVID-19 became a world health problem. This case began with information from the World Health Organization (WHO) on December 31, 2019, which stated that there was a cluster of pneumonia cases with unclear etiology in Wuhan City, Hubei Province, China. This case continues to grow until there are reports of deaths and importations outside China. On January 30, 2020, WHO designated COVID-19 as a Public Health Emergency of International Concern (PHEIC).

In an effort to prevent the spread of this virus, the government has taken several policy steps in various sectors, including in the field of education. In accordance with Circular Letter number 4 of 2020 dated March 24, 2020, the second point of the Minister of Education and Culture, regarding the learning process from home, lectures are conducted online, with students at home This of course will have various impacts for students, including students of the Department of Sports Education, Sport Science Faculty, Surabaya State University. Students majoring in Sports Education take many courses in each semester, especially sports practice courses in the field with high physical activity, but with the existence of an online lecture policy, many practical field courses are forced to not be done. This certainly affects student life, including the quality of life.

Quality of life as an understanding of existing value systems related to goals, standard expectations, and also individual attention to their life in society in a cultural context, individual physical conditions, psychology, level of independence and individual relationships with the environment are the effects of quality of life [10]. Another opinion states that quality of life is a functional condition which consists of physical health which 
includes the level of daily activity, the need to meet rest, sleep restlessness, dependence on medical aid, energy and fatigue, mobility, work capacity [2].

Quality of life as an individual's perception of their position in life in the context of the culture and value system in which they are included, which also involves their goals, perspectives, standards, and concerns [9]. The quality of life of people in the fields of physical health, environment, psychology and social relations is influenced by environmental quality [14]. It has been researched that active participation in sports activities is the most dominant factor associated with a better quality of life [4].

The level of physical activity has a big health impact. Lack of physical activity can increase the risk of obesity and obesity. Conversely, increased physical activity will reduce between $6 \%$ and $10 \%$ of NCD (noncommunicable disease) especially CHD (coronary heart disease), type 2 diabetes, and breast and colon cancer, and increase life expectancy [6]. There are many advantages and relationships between physical activity and health, including: 1) Physical activity helps maintain energy balance and prevents obesity, 2) Regular physical exercise reduces the risk of disease, 3) Regular physical exercise or a high level in daily activities can prevent several types of cancer, 4). Regular physical exercise can also prevent or lower blood pressure in people with hypertension [8].

Based on this description, students majoring in Sports Education who usually have quite a lot of physical activity related to their lectures will experience disturbances which are very likely to interfere with the quality of their life as well, so there is a need for research on the description of the quality of life and physical activity of students majoring in Department of Sports Education, Sport Science Faculty during the Covid-19 pandemic

\section{METHOD}

This research is a type of survey research. Where the researchers only describe the description of the quality of life and physical activity of students majoring in Sports Education, Sport Science Faculty, Surabaya State University without any treatment. The population in this study were all students of the 2019 Sports Education Department, totaling 190 students. The selection of research subjects using purposive sampling, students of the 2019 class who entered the inclusion criteria were 159 students consisting of 115 boys and 44 girls.
The test instrument is in the form of a questionnaire adapted from the WHO Quality of Life-BREF (WHOQOL-BREF) to measure the quality of life. This instrument is used to assess or determine the extent to which a person's quality of life in living their daily lives, there are 26 questions as well as 4 ways of calculating so that there are 30 columns in the question. This instrument is divided into four dimensions, namely physical health, psychological health, social relationships, environmental health. The results of the score for each dimension will be transformed into a score in standard norms.

Table 1. WHOQOL-BREF instrument quality of life categories

\begin{tabular}{|c|c|}
\hline Category & Transform Score Value \\
\hline Very Good & $76-100$ \\
\hline Good & $51-75$ \\
\hline Moderate & $26-50$ \\
\hline Poor & $0-25$ \\
\hline
\end{tabular}

Meanwhile, physical activity was measured using the International Physical Activity Questionnaire (IPAQ) The physical activity score is obtained from the METsminutes / week value which is the sum of walking, moderate activity, and strenuous activity in duration (minutes) and frequency (days), which is then multiplied by the value of each METs.

Table 2. IPAQ instrument level of physical activity categories

\begin{tabular}{|c|c|}
\hline Category & METs Value (minutes/week) \\
\hline Height & $>3000$ \\
\hline Moderate & $600-3000$ \\
\hline Low & $<600$ \\
\hline
\end{tabular}

Data were analyzed univarietaly with a frequency distribution and percentage.

\section{RESULTS AND DISCUSSION}

Based on research that has been conducted on 159 subjects of students of the Department of Sports Education, Faculty of Sports Science, the following results were obtained:

Table 3. Characteristics of subjects

\begin{tabular}{|c|c|c|c|c|c|}
\hline Class & $\mathbf{N}$ & $\begin{array}{c}\text { Age } \\
\text { (year) }\end{array}$ & $\begin{array}{c}\text { Weight } \\
(\mathbf{k g})\end{array}$ & $\begin{array}{c}\text { Height } \\
(\mathbf{c m})\end{array}$ & $\begin{array}{c}\mathbf{B M I} \\
\left(\mathbf{k g} / \mathbf{m}^{2}\right)\end{array}$ \\
\hline $\mathrm{A}$ & 42 & $19.04 \pm$ & $59.50 \pm$ & $164.33 \pm$ & $21.92 \pm$ \\
& 42 & 0.78 & 9.71 & 7.52 & 2.42 \\
\hline $\mathrm{B}$ & 40 & $19.09 \pm$ & $59.52 \pm$ & $166.25 \pm$ & $21.49 \pm$ \\
& 4 & 0.56 & 8.92 & 7.72 & 2.52 \\
\hline $\mathrm{C}$ & \multirow{2}{*}{41} & $19.28 \pm$ & $62.76 \pm$ & $168.23 \pm$ & $22.07 \pm$ \\
& 0.59 & 12.13 & 7.49 & 3.44 \\
\hline
\end{tabular}




\begin{tabular}{|c|c|c|c|c|c|}
\hline $\mathrm{D}$ & \multirow{2}{*}{36} & $18.92 \pm$ & $63.43 \pm$ & $168.31 \pm$ & $22.30 \pm$ \\
& & 0.66 & 11.79 & 7.07 & 3.27 \\
\hline \multirow{2}{*}{ Total } & \multirow{2}{*}{159} & $19.09 \pm$ & $61.23 \pm$ & $166.73 \pm$ & $21.94 \pm$ \\
& & 0.66 & 10.74 & 7.58 & 2.92 \\
\hline
\end{tabular}

The World Health Organisation Quality of Life assesment (WHOQol) is broad-ranging concept affected in complex way by the person's physical health,psychological state, personal beliefes and social relationship to salient features of environment (16)

Table 4. Physical health WHOQOL-BREF instrument

\begin{tabular}{|c|c|c|c|c|c|}
\hline Class & N & Mean \pm SD & Min & Max & Category \\
\hline A & 42 & $54.31 \pm 8.66$ & 31 & 69 & Good \\
\hline B & 40 & $54.20 \pm 9.20$ & 38 & 69 & Good \\
\hline C & 41 & $55.15 \pm 10.49$ & 31 & 81 & Good \\
\hline D & 36 & $54.14 \pm 9.12$ & 36 & 69 & Good \\
\hline Total & 159 & $54.46 \pm 9.27$ & 31 & 81 & Good \\
\hline
\end{tabular}

Physical health is not only caused by regular sports activities, but physical health is caused by several factors, including routine sports activities and according to the exercise dose, recovery duration, food intake, nutrition, and the adequacy of students in hydrating their bodies [1]. During a pandemic, student cannot exercise as usual, so it may reduce their physical health. But based on the results obtained, the dimensions of physical health in all classes showed good results. This shows that students seem to have a pattern of maintaining their physical health, which is very likely from the learning process during college.

Table 5. Psychological health WHOQOL-BREF instrument

\begin{tabular}{|c|c|c|c|c|c|}
\hline Class & $\mathbf{N}$ & Mean \pm SD & Min & Max & Category \\
\hline A & 42 & $63.38 \pm 10.77$ & 38 & 81 & Good \\
\hline B & 40 & $62.25 \pm 10.86$ & 38 & 81 & Good \\
\hline C & 41 & $61.59 \pm 11.73$ & 44 & 81 & Good \\
\hline D & 36 & $60.53 \pm 10.11$ & 31 & 75 & Good \\
\hline Total & 159 & $61.99 \pm 10.85$ & 31 & 81 & Good \\
\hline
\end{tabular}

Although the learning was carried out online and there were various obstacles in its implementation, the psychological health of students showed good average results in all classes. From the results of research by Hasanah et.al on the psychological description of students in the learning process during the Covid-19 pandemic ,it shows that the results of mild anxiety are the main psychological impact on students when studying online during the pandemic [17], but this does not appear to be the case for students in sports education departement,

Psychological health, which includes physical image, positive appearance and feeling, negative feelings, thinking, concentration, self-esteem, remembering, learning, and individual beliefs. Social relations include personal relationships, social support, and environmental conditions which include the home environment, physical safety, freedom, vehicles, security, activities in the environment, health, financial resources, and social care [5]. Social interaction affects the psychological condition of students. The better the social interaction, the better the quality of life and psychology of the students [12].

Table 6. Social health WHOQOL-BREF instrument

\begin{tabular}{|c|c|c|c|c|c|}
\hline Class & $\mathbf{N}$ & Mean \pm SD & Min & Max & Category \\
\hline A & 42 & $62.79 \pm 12.99$ & 44 & 94 & Good \\
\hline B & 40 & $66.45 \pm 10.05$ & 50 & 94 & Good \\
\hline C & 41 & $67.12 \pm 16.76$ & 31 & 100 & Good \\
\hline D & 36 & $64.08 \pm 14.14$ & 44 & 100 & Good \\
\hline Total & 159 & $65.12 \pm 65.12$ & 31 & 100 & Good \\
\hline
\end{tabular}

Social support is one of the factors that can improve the quality of life. The main and important social support is from parents, siblings, and family. A person will know to whom he will get social support according to the situation, so that social support can give meaning to both parties [13]. Especially in the current pandemic condition, social support from the closest people is very much needed so that physical and psychological health is maintained so that you can avoid Covid-19.

Table 7. Environment health WHOQOL-BREF instrument

\begin{tabular}{|c|c|c|c|c|c|}
\hline Class & $\mathbf{N}$ & Mean \pm SD & Min & Max & Category \\
\hline A & 42 & $60.81 \pm 11.85$ & 38 & 81 & Good \\
\hline B & 40 & $60.28 \pm 12.65$ & 31 & 94 & Good \\
\hline C & 41 & $63.51 \pm 13.89$ & 38 & 100 & Good \\
\hline D & 36 & $62.92 \pm 12.12$ & 44 & 100 & Good \\
\hline Total & 159 & $61.85 \pm 12.62$ & 31 & 100 & Good \\
\hline
\end{tabular}

The quality of life is related to the quality of life of other people in one environment [7]. Quality of life depends on a multidimensional contract which is 
influenced by personal factors and the surrounding environment. Quality of life is closely related to the environmental conditions used as a place to live. Joint efforts are needed to create an environment that can create a comfortable, pleasant, and peaceful atmosphere for its residents. Thus, this condition is needed by students. So that students will be supported by environmental conditions to achieve a good quality of life.

Table 8. Level of physical activity subjects

\begin{tabular}{|c|c|c|c|c|}
\hline Class & $\mathbf{N}$ & Mean \pm SD & Min & Max \\
\hline A & 42 & $3421.55 \pm 1337.90$ & 472.2 & 4940.0 \\
\hline B & 40 & $3165.96 \pm 1598.63$ & 240.0 & 5336.5 \\
\hline C & 41 & $3311.33 \pm 1544.56$ & 618.0 & 5326.0 \\
\hline D & 36 & $3376.78 \pm 1484.69$ & 595.5 & 5859.0 \\
\hline Total & 159 & $3318.69 \pm 1482.25$ & 240.0 & 5459.0 \\
\hline
\end{tabular}

Table 9. Percentage of physical activity level category

\begin{tabular}{|l|c|c|}
\hline Level of Physical Activity & $\mathbf{N}$ & Percentage \\
\hline Weigt & 93 & $58.5 \%$ \\
\hline Moderate & 61 & $38.4 \%$ \\
\hline Mild & 5 & $3.1 \%$ \\
\hline
\end{tabular}

Another factor that can improve a person's quality of life is by doing physical activity by improving psychological well-being and physical function. Active physical activity according to the Basic Ministry Research (Riskesdas) is an individual who does heavy or moderate physical activity or both, while the criterion for "less active" is individuals who do not do moderate or strenuous physical activity [3]. A person with a good quality of life will live life in society properly and according to his role, besides that of course also has good physical and spiritual health [11].

The results of research in the United States regarding the impact of the COVID-19 pandemic on physical activity and sedentary behavior in school-age children, it turns out that there is a decrease in physical activity and an increase in sedentary behavior which will increase the risk of obesity, diabetes and cardiovascular disease. [18], However, this seems to have a different outcome to the situation in sports education students.

Based on the results of the measurement of the physical activity level of students of the Sports Education Department, it shows good results with an average total activity of more than 3000 METs (height category). Even though students study from home, some practical courses require them to continue doing activities even at home.
Many of the students are involved in sports professionally, which requires them to keep training and keep in shape.

\section{CONCLUSION}

During the COVID-19 pandemic with online teaching and learning activities, the quality of life category of students in sports education is in the good category, with an average score of $51-75$ and the physical activity category of students in sports education is in the high category with an average total activity of more than 3000 METs. It is very necessary to maintain the quality of life and always improve the health and fitness of the body to avoid transmission of COVID-19.

\section{REFERENCES}

[1] Andriana, L., Ashadi, K., and Sandi, I.. "Olahraga di Lingkungan Indoor Pada Malam Hari Menghasilkan Rasio Keringat Lebih Banyak Dibandingkan Pagi Hari," Sport and Fitness Journal, vol. 7(3), pp. 53-62, 2019.

[2] Couture, M., Choulanard, C., Forth, M., \& Hudon, C. (2017). The Relationship Between Health Literacy and Quality of Life Among Frequent Users of Health Care Services: A Cross-Sectional Study. Health and Quality of Life Outcomes, 15(137), 1-6.

[3] Departemen Kesehatan RI. Riset Kesehatan Dasar. Jakarta: Badan Penelitian dan Pengembangan Kesehatan, 2013

[4] Dewi SK, Kusnanto H, Pramantara IDP, Rahayujati TB. "Status Partisipasi dan Kualitas Hidup Peserta Pos Pelayanan Terpadu Lanjut Usia," Kes Mas: Jurnal Kesehatan Masyarakat, vol. 11(1), pp. 28-40, 2017.

[5] Galilea, I., Buil, P., Salas, J., Toledo, E., Ortega, C., Díez, J., and Romaguera, D. "Mediterranean Diet and Quality of Life: Baseline Cross-sectional Analysis of the PREDIMED-PLUS trial," PloS one, vol. 13(6), pp. 1-18, 2018.

[6] Lee, I.-M., Shiroma, E. J., Lobelo, F., Puska, P., Blair, S. N., \& Katzmarzyk, P. T. "Impact of Physical Inactivity on the World's Major NonCommunicable Diseases," The Lancet, vol. 380(9838), pp. 219-229, 2012. 
[7] Loo, B. P., Mahendran, R., Katagiri, K., \& Lam, W. W. "Walking, Neighbourhood Environment and Quality of Life Among Older People," Current Opinion in Environmental Sustainability, vol. 25, pp. 8-13, 2017.

[8] Mustika, M. A. Tingkat Aktivitas Fisik, Tingkat Konsumsi Zat Gizi dan Status Gizi Siswa Di Pondok Pesantren Al Falak Kota Bogor, Bogor, 2012.

[9] Ribeiro, I. J., Pereira, R., Freire, I. V., de Oliveira, B. G., Casotti, C. A., and Boery, E. N. "Stress and Quality of Life Among University Students: A Systematic Literature Review," Health Professions Education, vol. 4(2), pp. 70-77, 2018.

[10] Schiavolin, S., Quintas, R., Pagani, M., Brock, S., Acerbi, F., Visintini, S., ... and Leonardi, M. "Quality of Life, Disability, Well-Being, And Coping Strategies in Patients Undergoing Neurosurgical Procedures: Preoperative Results in An Italian Sample," The Scientific World Journal, vol. 2014, 1-7, 2014.

[11] Schuch, F. B., Vancampfort, D., Rosenbaum, S., Richards, J., Ward, P. B., and Stubbs, B. "Exercise Improves Physical and Psychological Quality of Life in People with Depression: A Meta-Analysis Including The Evaluation of Control Group Response," Psychiatry research, vol. 30(241), pp. 47-54, 2016

[12] Supraba, P., Widarini, P., and Ani, S. "The Association Between Social Functions and Quality of Life among Elderly in Denpasar," Public Health and Preventive Medicine Archive, vol. 4(2), pp. 158-162, 2016.

[13] Widmer, E. D., Girardin, M., \& Ludwig, C. "Conflict Structures in Family Networks of Older Adults and Their Relationship with Health-Related Quality of Life," Journal of Family Issues, vol. 39(6), pp. 1573-1597, 2018.

[14] Wong, F. Y., Yang, L., Yuen, J.W., Chang, K.K., \& Wong, F.K. "Assessing quality of Life Using WHOQOL-BREF: A Cross-Sectional Study on the Association Betweet Quality of Life and Neighborhood Environmental Satisfaction, and the Mediating Effect of Health-related Behaviors," BMC Public Health, vol. 18(1), pp. 2-14, 2018.

[15] World Health Organization, "WHOQOL: Measuring Quality of Life," Psychol Med, vol. 28(3), pp. 551-558, 1998.

[16] Ducinskiene D, Kalediene R, Petrauskiene J. "Quality of Life Lithuanian University Students" Acta medica Lituanica.2003.

[17] Hasanah U,Ludiana,Immawati, livana PH Gambaran Psikologis mahasiswa dalam proses pembelajaran selama pandemi Covid-19. Jurnal Keperawatan Jiwa Vol (8) 3, pp 299-306. 2020

[18] Dunton GF, Do B, Wang SD. Early effects of the Covid-19 pandemic on physical activity and sedentary in children living in the UK. BMC Public Health $\quad \operatorname{vol}(20) \quad 1351 . \quad 2020$ 